\title{
NILAI KERUKUNAN DAN KEKELUARGAAN ETNIS JAWA DALAM \\ TRADISI AMONG-AMONG \\ (Studi Pada Etnis Jawa Di Desa Magelang Kecamatan Kerkap \\ Kabupaten Bengkulu Utara)
}

Oleh:

\author{
Yatiman, Anis Endang SM, Sri Narti \\ Program Studi Ilmu Komunikasi Fakultas Ilmu-Ilmu Sosial \\ Universitas Dehasen Bengkulu
}

\begin{abstract}
The tradition among all is a Javanese tradition carried out to commemorate the birthday of someone in the Javanese calendar. One of the Javanese who still carries out the traditions among the Javanese is in Magelang Village, Kerkap District, North Bengkulu Regency. This study aims to examine the value of harmony and family values of ethnic Javanese in the tradition of among those in the village of Magelang. The method of this research is qualitative research using Roland Barthes's semiotic analysis. Determination of informants in this study was purposive sampling and data collection using observation, indepth interviews and documentation. Based on the results of the study, it can be seen that Charcoal (symbolizing the furnace in the kitchen), money (all human needs purchased with money), rice (indicating cooked food), banana leaves (as a base for eating), red porridge (symbolizing maternal blood), porridge white (symbolizing father's sperm cells), fern leaves (as traditional medicine), dadap leaves (as traditional medicine when children are sick), eggs (as the center in ngepong emong), and urap (symbolizing ancient simplicity), while developing myths about the tradition of among the people is that this tradition is carried out to ask for the safety of the child to avoid being disturbed by supernatural beings. The value of harmony and family values of Javanese ethnic in Magelang Village are maintained and intertwined with the implementation of these traditions. The community still adheres to the philosophy "manganese manganese is important to collect" to become their foundation in maintaining harmony and kinship between them.
\end{abstract}

Keywords: tradition, ethnicity, value of harmony and family values

\section{PENDAHULUAN}

Masyarakat Indonesia sejak dulu sudah dikenal sangat heterogen dalam berbagai aspek, seperti adanya keberagaman suku bangsa, agama, bahasa, adat istiadat dan sebagainya. Banyaknya keanekaragaman budaya di Indonesia memberikan gambaran bahwa setiap suku yang ada memiliki identitas dan ciri khas yang menunjukkan perbedaan-perbedaan dari setiap suku. Perbedaan ini bukan untuk hal yang menjatuhkan melainkan sebagai alat pemersatu, sebab dari perbedaan-perbedaan yang ada tiap masyarakat akan saling menghargai budaya yang satu dengan yang lainnya. Tidaklah asing bagi kita sebagai warga Negara Indonesia dengan adanya perbedaan budaya di kalangan masyarakat kita, karena mengingat begitu luasnya wilayah Indonesia.

Budaya merupakan suatu cara hidup yang berkembang dan dimiliki bersama oleh sebuah kelompok orang dan 
diwariskan dari generasi ke generasi (Mulyana, 2005:237). Ketika seseorang berusaha berkomunikasi dengan orangorang yang berbeda budaya dan menyesuaikan perbedaan-perbedaannya, disitulah dibuktikan bahwa sebenarnya budaya itu juga dipelajari.

Setiap budaya yang ada di Indonesia memiliki tradisi masing-masing. Tradisi-tradisi yang telah ada bukan berarti tidak memiliki makna, melainkan sudah memiliki makna dan tujuannya yang akan dicapai karena memiliki keinginan bersama antar masyarakat. Timbulnya tradisi dalam kelompok manusia atau masyarakat dianggap baik oleh masyarakat itu sendiri dan itu akan menjadi warisan terhadap keturunannya (repository.2014). Tradisi-tradisi yang turun-temurun inilah yang nantinya lahir menjadi sebuah budaya yang menjadi identitas suatu masyarakat tertentu (repository.2014). Tradisi-tradisi seperti upacara tradisional, tari-tarian, lagu-lagu, permainan tradisional serta olahraga tradisional seluruhnya merupakan warisan leluhur yang harus dilestarikan dan dijaga keberadaannya.

Salah satu contoh masyarakat yang sampai saat ini masih tetap melestarikan tradisi leluhur adalah masyarakat Jawa. Orang Jawa masih sangat melestarikan tradisi warisan dari nenek moyang untuk menghormati leluhur dan sebagai penguat nilai-nilai budaya dan adat istiadat yang ada. Bukan hanya masyarakat Jawa yang ada di pulau asalnya saja yang masih terus melestarikan atau melaksanakan adatistiadat ini. Masyarakat Jawa yang ada di Pulau Sumatera seperti di Provinsi Bengkulu tepatnya di Desa Magelang Kecamatan Kerkap Kabupaten Bengkulu Utara yang berasal dari transmigrasi Magelang Jawa Tengah ini juga masih terus melaksanakan tradisi-tradisi warisan leluhur. Sebagai salah satu daerah di Provinsi Bengkulu dengan mayoritas penduduk suku Jawa, masyarakat Desa Magelang percaya bahwa dengan melaksanakan tradisi-tradisi tersebut akan terhindar dari ganguan-ganguan makhluk lain, terjaga keselamatannya dan terhindar dari marabahaya.

Padahal yang kita ketahui bersama bahwa di era sekarang ini, masyarakatnya sudah modern dan untuk tradisi sudah mulai luntur kerena dalam tradisi memiliki banyak proses. Namun berbeda dengan masyarakat di Desa Magelang karena sampai saat ini mereka masih tetap melaksanakan tradisi Jawa di tengah terpaan budaya-budaya lain. Salah satu bentuk tradisi yang masih terus dilaksanakan adalah tradisi among-among. Tradisi among-among biasa dilakukan oleh masyarakat Jawa pada saat memperingati hari kelahiran bayi (Nepton) dalam penanggalan Jawa. Among-among biasa dilakukan oleh masyarakat tanpa ada batasan sampai umur berapa bayi tersebut. Namun biasanya among-among dilaksanakan mulai dari bayi berumur 40 hari sampai 4-5 tahun tergantung dari kebutuhan dan kemampuan orang tuanya untuk membuatkan among-among. Jika di Desa Magelang among-among juga dilaksanakan untuk seseorang yang usianya sudah dewasa, bukan hanya untuk bayi sebagaimana umumnya, tergantung dengan kebutuhan.

Secara singkat dapat digambarkan bahwa tradisi among-among adalah tradisi makan bersama yang dilakukan oleh anakanak. Cara makannya pun berbeda dengan cara makan kita pada umumnya. Pada tradisi among-among ini seluruh makanan dimasukkan kedalam satu piring. Didalam piring tersebut ada nasi, kuluban (sayuran), daun pakis (daun paku), daun dadap, telur yang dibelah menjadi beberapa bagian dan lauk pauk lainnya serta bubur yang diletakkan di sebelah piring tersebut. Tidak lupa juga alas yang digunakan adalah daun pisang, dimana dibawah daun pisang tersebut dimasukkan beras secukupnya, arang kayu serta uang.

Disetiap peralatan serta bahanbahan yang digunakan selalu mempunyai 
makna tersendiri. Terkesan proses tradisi among-among ini sangatlah susah, mulai dari persiapan memasak makanan untuk among-among, mengundang anak-anak untuk ngepong (meramaikan) amongamong hingga proses tradisi tersebut selesai.

Di Desa Magelang sendiri, masih banyak masyarakat yang melaksanakan tradisi among-among namun mereka kurang mengerti akan makna dibalik semua itu. Selain itu, untuk di kota Bengkulu belum pernah dijumpai tradisi among-among ini, termasuk orang Jawa yang menetap atau tinggal di Kota tersebut. Masyarakat di perkotaan cenderung lebih modern yang sedikit demi sedikit mulai meninggalkan tradisi warisan leluhur. Maka dari itu dalam penelitian ini penulis merasa tertarik untuk mengangkat judul penelitian yaitu "Analisis Nilai Kekeluargaan Dan Kebersamaan Etnis Jawa Di Sumatera Dalam Tradisi AmongAmong". Dengan adanya penelitian ini akan terungkap nilai kekeluargaan dan kebersamaan yang terkandung dalam proses serta simbol yang digunakan dalam tradisi among-among ini, serta diharapkan kepada para pembaca agar tetap melestarikan budaya atau tradisi warisan leluhur kita.

Penelitian ini menggunakan analisis semiotika Roland Barthes, yang terdiri dari tiga tingkatan yaitu denotasi, konotasi dan mitos. Analisis semiotika di rasa sebagai metode yang paling tepat untuk mengetahui nilai kekeluargaan serta kebersamaan yang terkandung pada tradisi among-among di Desa Magelang Kecamatan Kerkap Kabupaten Bengkulu Utara.

\section{METODE PENELITIAN}

Dalam penelitian ini, peneliti menggunakan metode penelitian kualitatif. Fokus kajian penelitian ini adalah ingin mengetahui nilai kerukunan dan kekeluargaan masyarakat Jawa dalam tradisi among-among. Pada penelitian ini, digunakan metode analisis semiotik yaitu metode yang menganalisis tentang tanda. Metode analisis semiotik yang akan digunakan dalam penelitian ini adalah metode pemikiran Roland Barthes.

\section{Sumber Data}

Sumber data yang digunakan menggunakan data primer dan sekunder. Data primer yang digunakan dalam penelitian ini yaitu :

\section{Informan kunci}

Informan kunci dalam penelitian ini adalah Tumingin dan Kaminem sebagai sesepuh dan lembaga adat Desa Magelang.

\section{Informan pokok}

Informan pokok dalam penelitian ini adalah masyarakat yang sedang melaksanakan tradisi among-among untuk anaknya yaitu Sri Yanti dan Dewi Murdaningsih.

\section{Teknik Pengumpulan Data}

Teknik pengumpulan data yang dilakukan yaitu dengan wawancara, observasi dan dokumentasi.

\section{Teknik Analisa Data}

Teknik analisis yang digunakan yaitu analisis semiotik. Lalu dari analis tersebut dibuat analisis deskritifnya dari makna denotasi dan konotasi. Langkahlangkah yang di ambil dalam menganalisa data adalah sebagai berikut:

\section{Menganalisis makna denotasi dan konotasi serta mitos dari tradisi among- among tersebut.}

Pada tahap denotasi penulis menganalisis bagian-bagian yang ada pada tradisi among-among tersebut. Dalam tradisi tersebut terdapat bubur berwarna merah dan putih, kemudian nasi, kuluban (sayuran), daun paku dan daun dadap, sambal kering, telur, arang, uang loga, serta beras. Penulis menganalisis satu persatu, mulai dari warna serta bentuk. 
Setelah itu penulis juga menganalisis tahap konotasi. Pada tahap konotasi penulis akan menganalisis makna dibalik bagianbagian dari tradisi among-among dengan menambahkan semua gambaran, ingatan serta perasaan yang ditimbulkan ketika melihat bagian-bagian dari tradisi tersebut.

\section{Menganalisis nilai kerukunan dan kekeluargaan masyarakat Jawa dalam tradisi among-among.}

Dengan mengikuti proses dari tradisi among-among ini, penulis dapat melihat dibagian mana saja yang terdapat nilai kerukunan dan kekeluargaan masyarakat Jawa..

\section{HASIL PENELITIAN DAN PEMBAHASAN}

Dalam hal ini, peneliti menggunakan teori Roland Barthes yang dikenal sebagai salah satu pemikir strukturalis yang sering mempraktekkan model linguistic dan semiologi Saussure. Teori Barthes menjelaskan dua tingkat pertanda yaitu denotasi dan konotasi. Denotasi adalah hubungan eksplisit antara tanda dan referensi atau realitas dalam pertandaan, sedangkan konotasi adalah aspek makna yang berakitan dengan perasaan dan emosi serta nilai-nilai kebudayaan dan ideologi. Tujuan menggunakan teori ini adalah untuk mengkaji makna tanda-tanda dalam tradisi among-among di desa magelang Kecamatan Kerkap Kabupaten Bengkulu Utara. Dimana dengan pemaknaan dua tahap denotasi dan konotasi yang digunakan oleh Roland Barthes dapat memberikan makna pada sebuah tanda berdasarkan kebudayaan yang melatar belakangi munculnya makna tersebut. Dengan demikian makna pada tataran mitos dapat dikemukakan sesuai dengan keunggulan semiotik Roland Barthes yang terkenal dengan elemen mitosnya. Alasan digunakan penelitian ini, pertama bahwa objek yang akan dikaji untuk diungkap maknanya adalah tanda, lambang, bahkan simbol yang ada pada tradisi amongamong. Karena itu menurut peneliti jenis penelitian kualitatif adalah penelitian yang tepat untuk digunakan. Kedua, model Roland Barthes yang di pilih. Karena model inilah yang memberikan kedalaman ketika memaknai sebuah tanda dalam tradisi.

Dari hasil penelitian ini, ditemukan adanya makna yang mencakupi denotasi, konotasi dan mitos. Berdasarkan teori semiotik Roland Barthes kemudian peneliti akan menganalisis penelitian ini berdasarkan tanda, mulai dari makna yang berdasarkan apa yang nampak (Denotasi), makna mendalam yang berkaitan dengan pemahaman ideologi dan cultural (Konotasi), dan makna hubungan konotasi dan denotasi secara mendalam (Mitos).

Hasil penelitian yang ditemukan bahwa Desa Magelang adalah desa yang mayoritas masyarakatnya Suku Jawa. Keturunan Jawa mereka berasal dari orang tua yang memang berasal dari Magelang Jawa Tengah. Di Desa Magelang ini sudah terbentuk suatu lembaga yang mengurusi tentang tradisi yaitu Lembaga Adat Desa. Lembaga adat desa ini sudah terbentuk sekitar satu tahun. Lembaga adat ini mengurusi semua yang berkenaan dengan tradisi, dalam hal ini tradisi Jawa. Salah satu tradisi Jawa yang masih tetap terus dilaksanakan adalah tradisi among-among. Tradisi ini sudah dilaksanakan semenjak Desa Magelang ini ditransmigrasikan dari Magelang Jawa Tengah ke Provinsi Bengkulu.

Berdasarkan hasil penelitian, masyarakat Desa Magelang melaksanakan tradisi among-among disetiap hari nepton anak. Nepton seseorang tersebut dapat diketahui berdasarkan perpaduan hari dalam Jawa dengan hari pada umumnya. Jumlah hari dalam Jawa hanya berjumah 5 hari (legi, pahing, pon, wage, kliwon), berbeda dengan jumlah hari pada umumnya yang memiliki jumlah 7 hari (senin, selasa, rabu, kamis, jumat, sabtu, dan minggu). Siklus penanggalan Jawa ini 
berjumlah 35 hari yang disebut dengan pasaran. Maka disetiap 35 hari sekali akan ada hari nepton seseorang.

Tradisi among-among ini dilaksanakan rutin mulai dari hari kelahiran anak itu sampai umur 3 bulan. Setelah sampai umur 5 tahun biasanya dilaksanakan dalam satu tahun satu kali. Bukan hanya sampai lima tahun saja, namun terkadang sudah dewasa pun masih tetap dibuatkan among-among dan itu tergantung kebutuhan. Alasan tradisi ini masih terus dilakasanakan adalah untuk meminta keselamatan, kesehatan dan dijauhkan dari makhluk gaib serta marabahaya terutama ketika anak tersebut sedang sakit. Ketika seorang anak mendekati hari nepton biasanya anak lebih rewel maka dari itu dibuatkanlah amongamong ini.

Secara umum tradisi among-among adalah Tradisi yang dilaksanakan untuk memperingati hari kelahiran seseorang dalam penanggalan Jawa. Dalam penanggalan Jawa itu hanya memiliki 5 hari yaitu wage, kliwon, pahing, pon, legi. Berbeda dengan hari nasional yang biasanya ada 7 (Senin, Selasa, Rabu, Kamis, Jumat dan Sabtu). Among-among merupakan bentuk wujud rasa syukur orang tua kepada leluhur. Di era sakarang ini tradisi among-among mirip dengan birthday party karena tujuannya untuk memperingati hari kelahiran seseorang, yang membedakan adalah proses pelaksanaannya. Dalam tradisi amongamong menggunakan nasi yang diberi sayur mayur, tidak lupa juga di doakan oleh sesepuh atau orang tua anak yang di among-among. Sedangkan jika dalam birthday party menggunakan kue dan menggunakan hiburan seperti organ tunggal. Dalam tradisi among-among terdapat beberapa bahan yang digunakan seperti arang, beras, uang, daun pisang, bubur merah, bubur putih, daun pakis, daun dadap, telur, dan urap.

Arang dalam tradisi among-among melambangkan bahwa nanti ketika kita sduah dewasa dan berumah tangga pasti akan ada perapian di dapur. Perapian itu bisa berupa tungku dengan cara memasak tradisional maupun tungku dengan kompor gas. Beras melambangkan yang akan dimasak, baik itu nasi maupun sayur mayur. Sedangkan uang digunakan sebagai uang wajib. Dalam hal ini uang digunakan sebagai pengganti jika ada barang-barang atau bahan-bahan yang digunakan tidak tersedia maka dengan uang tersebut bisa mencari sendiri. Berbeda lagi dengan daun pisang yang digunakan sebagai alas pembatas antara nasi serta sayur yang berada dibagian atas dengan arang, beras dan uang yang ada dibagian bawah. Selain itu, tata cara peletakan dalam tradisi among-among ini daun pisang yang memiliki serbuk putih seperti bedak itu dibagian atas sedangkan jika bagian daun yang hijau pekat dibagian atas maka itu digunakan untuk mendoa orang yang sudah meninggal.

Selanjutnya adalah bubur merah. Bubur merah yang terbut dari beras yang dimasak sedikit lama hingga menjadi bubur. Tidak lupa juga ditambahkan gula merah sebagai pewarna. Warna merah pada bubur ini melambangkan darah yang keluar ketika seorang ibu melahirkan seorang anak. Jadi secara umum bubur merah itu melambangkan roh seorang ibu. Berbeda dengan bubur merah, bubur putih itu melambangkan roh seorang bapak. Warna putih pada bubur ini diibaratkan sebagai sel sperma seorang bapak atau ayah. Mereka berdualah yang kemudian merawat dan membesarkan kita hingga kita dewasa. Jika daun pakis itu dipercaya sebagai lambang ketenangan. Ketenangan dalam hal ini agar tidak diganggu oleh makhluk gaib dan dijauhkan dari marabahaya. Setelah itu daun dadap, daun dadap dipercaya sebagai lambang kesehatan. Dalam keseharian daun dadap digunakan sebagai media pengkompres jika seorang anak sakit atau demam. Selanjutnya adalah telur, telur yang dipotong menjadi 4 bagian ini 
melambangkan bahwa manusia yang hidup itu memiliki empat saudara yang tidak dapat dilihat oleh mata atau tak kasat mata. Dan yang terakhir adalah urap, urap adalah jenis makanan yang terbuat dari campuran sayur mayur yang dicarop atau dicampurkan dengan parutan kelapa yang sudah dibumbui. Dalam tradisi amongamong, urap melambangkan manusia yang berbeda-beda suku, agama serta ras namun tetap nyarop atau nyampur antara satu sama lainnya. Perbedaan bukan menjadi alasan suatu perpecahan.

Di era modern seperti saat ini, begitu banyak budaya-budaya yang masuk dan berkembang disuatu masyarakat yang menyebabkan perubahan suatu tradisi. Namun berbeda dengan Etnis Jawa yang ada di Desa Magelang ini, mereka masih tetap melaksanakan suatu tradisi sesuai dengan apa yang dulu pernah dilaksanakan oleh para pendahulu mereka. Mereka tidak pernah merubah atau menambahkan bahan-bahan serta peralatan yang digunakan hingga dalam proses pelaksanaannya. Jika ada bahan-bahan yang susah atau sulit ditemukan seperti daun dadap dan daun pakis, mereka tidak menggantinya dengan yang lain. Namun jika di Desa Magelang karena tradisi among-among sudah menjadi tradisi maka mereka berinisiatif untuk menanam daun pakis dan daun dadap itu dipekarangan rumah sehingga ketika dibutuhkan akan mudah ditemukan.

Proses pelaksanaan tradisi amongamong ini berawal dari memasak makanan yang akan dimakan. Dalam proses memasak orang tua yang menyelenggarakan tradisi among-among ini dibantu oleh sanak saudara dan tetangga sekitar. Tetangga sekitar mengetahui bahwa orang tersebut hendak melaksanakan tradisi among-among untuk anaknya dari perbincangan yang mereka sering lakukan sehari-hari. Kemudian sanak saudara dan tetangga membantu memasak makanan yang dibutuhkan untuk pelaksanaan tradisi ini di rumah orang tersebut. Ketika memasaka mereka saling membagi tugas, ada yang mencari dan memarut kelapa, kemudian ada yang membersihkan bumbu-bumbu, dan ada yang memasak bubur. Untuk bahanbahannya pun jika orang yang ingin melaksanakan tradisi ini belum memiliki, mereka membawakan dari rumah mereka masing-masing. Dari sini sudah terdapat nilai kekeluargaan diantara mereka dengan rasa tanggung jawab sosial, karena pada dasarnya manusia adalah makhluk sosial yang saling membutuhkan bantuan orang lain, rasa belas kasihan dan rasa kemurahan hati untuk saling tolong menolong tanpa diminta bantuan.

Setelah semua masakan selesai dimasak, hal yang dilakukan selanjutnya adalah mencari anak-anak yang diajak untuk mengepong atau mengelilingi tradisi among-among ini. Selain mengundang anak-anak, orang tua yang menyelenggarakan tradisi ini juga mengundang imam atau sesepuh untuk diminta tolong mendoakan dalam tradisi among-among ini. Dalam tradisi ini, anakanak yang diundang adalah anak-anak yang ada disekeliling rumah serta anak dari sanak saudara mereka sendiri. Setelah anak-anak berkumpul, kemudian mereka berdoa untuk keselamatan anak yang di among-amongi tersebut serta berdoa untuk keselamatan keluarga mereka. Selanjutnya adalah makan bersama dalam satu piring. Dari proses pelaksanaan tradisi ini dapat dilihat bahwa keluarga penyelenggara dengan tetangga serta sanak saudara berhubungan akur dan rukun. Terbukti dengan mereka bersedia datang untuk menghadiri pelaksanaan tradisi amongamong ini untuk anaknya. Mereka menghormati undangan yang ditujukan kepadanya dengan datang dalam acara tersebut. Mereka juga menghargai kebersamaan dengan makan satu piring bersama-sama. Walaupun yang datang itu berasal dari suku Jawa, Rejang, dan Padang namun mereka tetap menghargai kebersamaan itu tanpa adanya rasa malu, 
rasa jijik karena mereka makan dalam satu piring secara bersama-sama.

Ketika dalam proses pelaksaannya, sesepuh atau orang tua yang dituakan dalam tradisi itu tidak menjelaskan kepada anak-anak yang mengepong atau mengelilingi nasi among-among tersebut. Mereka beranggapan bahwa jika di jelaskan mereka juga belum mengerti karena masih terlalu dini. Karena masih terus dilaksanakan dan ditekankan kepada generasi penerus untuk tetap dilaksanakan maka secara otomatis mereka juga akan mengerti dengan sendirinya. Dengan penekanan untuk terus dilaksanakan maka tradisi yang sudah turun-menurun ini tidak akan punah dan akan selalu ada untuk generasi selanjutnya.

Dalam tradisi among-among terdapat beberapa nilai yang terkandung seperti nilai kebersamaan, nilai saling berbagi, nilai kerukunan, nilai kesederhanaan dan nilai kekeluargaan. Dalam penelitian ini, peneliti hanya berfokus pada nilai kerukunan dan kekeluargaan. Nilai-nilai terebut terdapat pada peralatan yang digunakan seperti daun pisang dalam tradisi among-among ini memiliki nilai kerukunan yang mana walaupun menjadi pembatas antara makanan yang ada diatas dan bahan-bahan yang ada dibagian bawah, daun pisang tetaplah menjadi kesatuan bahan yang digunakan. Seperti layaknya manusia, dengan dipisah bukan berarti mereka pecah belah dan jika disatukan mereka tetaplah berbeda namun masih bisa saling manghargai dan mnghormati perbedaan serta tidak berselisih diantara mereka. Selanjutnya bubur merah dan bubur putih yang memiliki nilai kekeluargaan. Bubur merah melambangkan roh ibu dan bubur putih melambangkan roh bapak. Mereka lah yang nantinya akan merawat kita dan membesarkan kita hingga dewasa. Maka kita sebagai seorang anak harus patuh dan tidak boleh melawan orang tua. Mereka telah banyak berkorban untuk kita, sehingga kita harus selalu menghayati pengorbanan mereka sebagai tindakan balas budi kita kepada mereka.

Pada telur juga terdapat nilai kerukunan dan kekeluargaan yaitu telur yang dibelah menjadi empat bagian ini dipercaya sebagai "sedulur papat limo pancer” yang mana kita sebagai seorang individu memiliki saudara gaib 4 orang yang akan selalu ada disamping kita. Maka dari itu kita dalam hidup berkeluarga harus saling rukun tanpa adanya rasa berselisih, harus sehati dan selaras sehingga terciptanya keluarga yang didasarkan atas rasa cinta. Selain itu urap juga memiliki nilai kerukunan dan kekeluargaan yang mana urap berasal dari berbagai jenis sayuran dan disatukan dengan kelapa parut. Seperti layaknya manusia yang berasal dari berbagai suku dan agama serta budaya yang berbeda namun tetap bisa bersatu, seperti contohnya dalam tradisi ini. Mereka membantu memasak dan hadir dalam tradisi among-among walaupun mereka berbeda suku serta budaya. Mereka mmeiliki rasa tangguung jawab sosial yang tinggi, keprihatinan terhadap sesame dan beas kasihan yang mana itu sesuai dengan indikator dalam nilai kekeluargaan. Mereka juga sehati dan selaras serta menerima da saling menghormati dan menghargai sesama yang hal ini sesuai dengan indikator dalam niai kerukunan.

Secara umum, nilai kerukunan dalam tradisi ini terdapat pada tradisi makan bersama yang dilaksanakan. Makan bersama dalam satu piring dan saling berbaur dengan tetangga, teman serta keluarga itu melambangkan bahwa mereka saling akur antara satu dengan yang lainnya. Bukan hanya itu saja, dengan mengundang tetangga dan kerabat dekat itu sudah menunjukkan bahwa diantara mereka tidak terjadinya perselisihan atau dengan kata lain sebagai tetangga mereka rukun dan akur.

Sedangkan untuk nilai kekeluargaannya, tradisi ini menunjukkan bahwa kasih sayang orang tua itu tidak pernah hilang. Mereka selalu sayang 
kepada anaknya. Mereka selalu ingat dengan hari-hari yang dianggap bersejarah dan penting bagi seorang anak. Selain itu nilai kekeluargaannya adalah mereka selalu bersama-sama dan bergotongroyong dalam segala hal. Mereka saling membantu dalam suka maupun duka. Seperti halnya dalam tradisi among-among ini, mereka memasak dan mempersiapkan secara bersama-sama. baik itu keluarga ataupun tetangga mereka saling membantu. Budaya gotong royong ini sampai saat ini masih terus dilaksanakan baik itu dalam pelaksanaan sebuah tradisi, resepsi pernikahan maupun dalam hal duka sekalipun.

Dengan masih tetap menganut filosofi Jawa "mangan ora mangan seng penting kumpul” yang artinya makan tidak makan yang penting kumpul itu sudah menandakan bahwa masyarakat Jawa lebih mengutamakan kerukunan dan kekeluargaan dengan berkumpul bersama. Walaupun tidak makan-makan mereka tetap berkumpul agar selalu terjaganya kerukunan sehingga rasa kekeluargaan mereka tetap terjalin. Mereka tidak mengutamakan kepentingan individu dalam hal ini dilambangkan oleh "mangan" yang menunjukkan suatu kebutuhan mendasar suatu makhluk hidup. Sedangkan kerukunan dan kekeluargaan adalah kebutuhan sosial masyarakat. Dengan demikian kebutuhan individu jika perlu ditinggalkan demi kebutuhan sosial tetap terjalin

\section{PENUTUP}

\section{Kesimpulan}

Adapun hasil yang dapat penulis simpulkan dalam penulisan ini yaitu:

1. Dalam tradisi among-among, peralatan yang digunakan ada 10 jenis yang memiliki makna, yaitu arang (melambangkan tungku di dapur), uang (semua kebutuhan manusia di beli dengan uang), beras (menandakan makanan yang dimasak), daun pisang (sebagai alas makan), bubur merah (melambangkan darah ibu), bubur putih (melambangkan sel sperma ayah), daun pakis (sebagai obat tradisional), daun dadap (sebagai obat tradisional ketika anak sakit), telur (sebagai pusat dalam ngepong emong), dan urap (melambangkan kesederhanaan zaman dahulu)..

2. Dengan adanya tradisi among-among di desa Magelang, menunjukkan bahwa masyarakatnya rukun dan akur dengan tetangga serta sanak saudara, ini terlihat dari mereka yang mengundang tetangga serta sanak saudara untuk mengepong amongamong, yang di undang pun juga menghormati dan menghargai undangan tersebut dengan menghadiri pelaksanaan tradisi tersebut. Dalam proses masak-masak untuk pelaksanaan tradisi ini pun mereka juga saling tolong-menolong dengan alasan agar rasa kekeluargaan mereka semakin erat. Mereka juga sadar bahwa manusia adalah makhluk sosial yang saling membutuhkan bantuan. Maka dari itu mereka saling tolong menolong dalam segala hal. Walaupun tidak diminta tolong mereka rela menolong dengan ikhlas.

\section{Saran}

Adapun saran yang dapat di kemukakan dalam penelitian ini adalah sebagai berikut ;

1. Bagi masyarakat, agar dapat dijadikan wawasan dan ilmu bahwa tradisi adalah suatu warisan nenek moyang yang perlu dilestarikan agar generasi penerus kita masih bisa melaksanakan dan melihatnya. Kemudian untuk orang tua maupun sesepuh agar mengajarkan dan memberikan pemahaman mengenai tradisi amongamong ini kepada anak-anak agar ketika mereka beranjak dewasa sudah mengerti dan paham dengan makna serta proses dalam tradisi ini. 
2. Bagi penelitian yang akan datang, hasil penelitian ini diharapkan dapat dijadikan sebagai dasar pengembangan penelitian dimasa yang akan datang dengan menggunakan pemikiran semiotik yang serupa, ataupun menggunakan pemikiran semiotik yang lain. Selain itu, penelitian yang serupa juga bisa dilaksanakan dengan menggunakan metode yang berbeda, misalnya dengan menggunakan metode kuantitatif yang akan mengungkapkan temuan-temuan yang lebih komprehensif dan dapat digeneralisasi.

\section{DAFTAR PUSTAKA}

Arikunto, Suharsimi. 2006. Prosedur Penelitian:Suatu Pendekatan Praktik. Jakarta: Rineka Cipta

Endraswara, Suwardi. 2003. Falsafah Hidup Jawa. Tanggerang: Cakrawala

Gunasasmita, R. 2009. Kitab Primbon Jawa Serbaguna. Yogyakarta: Narasi

Koentjaraningrat. 2009. Pengantar Ilmu Antropologi. Jakarta: PT Rineka Cipta
Kriyantono, Rachmat. 2008. Public Relation Writing. Jakarta: Kencana Prenada

Latif, M. Syahbudin. 2000. Persaingan Calon Kepala Desa Di Jawa. Yogyakarta : Media Presindo

Lubis, Ridwan. 2005. Cetak Biru Peran Agama. Jakarta: Puslitbang

Maryaeni. 2012. Metode Penelitian Kebudayaan. Jakarta: PT Bumi Aksar

Moloeng, Lexy J. 2002. Metodologi Penelitian Kualitatif. Bandung: Remaja Rosdakarya 